\title{
ファイバーブラッググレーティングの製作 ${ }^{+}$ \\ 中 川 清* 江 島 正 毅**
}

\section{Fabrication of Fiber Bragg Grating Structure}

by

\author{
Kiyoshi NaKagawa ${ }^{*}$ and Seiki EJIMA ${ }^{* *}$
}

Key words : Bragg gratings, Optical fiber devices, Optical fiber filters, Optical fiber sensors

\section{1 は じめに}

ファイバーブラッググレーティング (Fiber Bragg Grating (FBG)) は, 光波の干渉パターンを光ファイバー に照射することで形成された，光ファイバー長手方向に 沿った屈折率の周期的変動構造である. ${ }^{1}$ 光ファイバー内 に形成された FBG は，ブラッグ波長と呼ばれる特定波 長の光波を選択的に反射するファイバー型光学部品とし て使用される.FBGはファイバー内に直接構成されてい るため, 低損失で信頼性が高く, 通信用光ファイバーと の親和性がよい.このため, 光通信用の光学部品として 開発が進められている. ${ }^{2}$ また，ブラッグ波長は FBG の周 辺温度やひずみに敏感に応答して変化することから，光 ファイバー型センサーとしての利用も検討されている. 本報ではまず, FBGの構成原理とその光学特性の解析原 理について述べる，そのあと，著者らが行っている FBG の製作方法を具体的に紹介する。また，FBG 製作の過程 で観測された FBGの光学特性についても紹介する．最 後にFBGの研究動向と課題について述べる.

\section{2 ファイバーブラッググレーティングの}

\section{構造と特性解析原理}

光ファイバーは，コアと呼ばれる光を導波する部分と その周りのクラッドと呼ばれる部分で構成されている. コア部は，クラッド部よりも屈折率を高く設定すること が必要で，一般的には $\mathrm{Ge}$ を添加した石英で作られる。 FBG は，この Ge 添加石英が波長 $240 \mathrm{~nm}$ 帯の紫外領域 光を吸収したとき，その屈折率が増加する現象を利用し て製作される。 Ge 添加石英中に存在する吸収準位のひ とつである GeE' 中心は, 波長 $240 \mathrm{~nm}$ 帯の光を吸収す ることにより欠陷構造が変化し, 吸収スペクトルの形状 が変化する。攵の結果，クラマース・クローニッヒの関

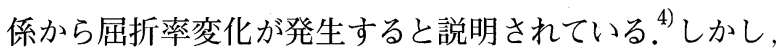
このメカニズムによる屈折率の変化量は小さく, 実際に 生じている変化量を充分には説明できない.ガラスの物 理的構造の変化など, 複数のメカニズムの複合現象で屈

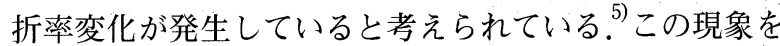
利用して, 紫外領域光の明暗パターンを光ファイバー側 面から照射することで FBG 構造は形成される.

FBG の解析モデルを図 1 に示す. 光ファイバー中の長 手方向について, FBG 構造は屈折率の分布 $n(z)$ として,

$$
n(z)=\bar{n}+\Delta n \cos \left(\frac{2 \pi}{\Lambda} z\right)
$$

で表せると考える. ${ }^{6)}$ ただここで, $\bar{n}$ は平均屈折率， $\Delta n$ は屈折率変化の振幅, $\Lambda$ は屈折率変化の周期である. FBG は $z=0$ からまで存在するとする. 石英ファイバー の場合 $\bar{n} \approx 1.5$ 程度であり, 屈折率変化 $\Delta n$ はたかだか 0.01 程度である. $(\Delta n \ll \bar{n})$

シングルモードファイバーに形成された FBG に係わる 光波の伝ぱは, 基底モードのみで, お互い反対方向に伝 ぱする二つの光波のみを考慮すれば良い，そこで, FBG に係わる光電場を，

$$
U(z)=A(z) \exp [-i \beta z]+B(z) \exp [i \beta z]
$$

のように, FBG に向かって進行する前進伝ぱ波 $A(z)$ と後 退伝ぱ波 $B(z)$ の和で表す。この時 $\beta$ は伝ぱ定数である. この 2 波が屈折率変化周期 $\Lambda$ の FBG に係わるためには, ブラッグ回折の条件

$$
\beta-(-\beta)=\frac{4 \pi \bar{n}}{\lambda}=m \frac{2 \pi}{\Lambda}
$$

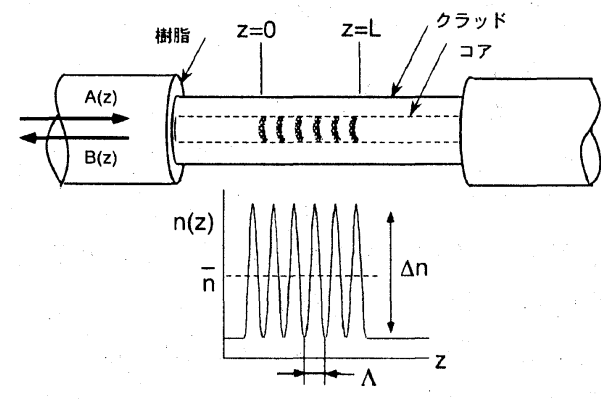

図 1 FBGの解析モデル

$\dagger \quad$ 原稿受理 平成 14 年 5 月 23 日 Received May 23, 2002

* 香川大学工学部信頼性情報システム工学科％761-0396 高松市林町, Dept. of Reliability Based Information Systems Eng., Kagawa Univ., Hayashi-machi, Takamatsu, 761-0396

** 正 会 員 香川大学工学部材料創造工学科 ₹761-0396 高松市林町, Dept. of Advanced Material Sci., Kagawa Univ., Hayashi-machi, Takamatsu, 761-0396 
を満たすことが必要である。ここで，入は光波の波長， は回折次数を表している. 式 (3) は, 周期 $\Lambda$ の屈折率変 化構造のどの部分で反射した光波も位相が等しくなるよ うな条件（位相整合条件）を表している.'1 1 次の回折を 考えた場合 $(m=1), \mathrm{FBG}$ により結合される 2 波の波長 はFBGの格子間隔 $\Lambda$ で制限され，

$$
\lambda_{B}=2 \bar{n} \Lambda
$$

で与えられるブラッグ波長 $\lambda_{B}$ の光波のみが結合される. つまり, 式 (1)で特徴付けられる FBG では, ブラッグ波 長 $\lambda_{B}$ の光波のみが反射され, それ以外の光波は, FBG を通過する。

FBG に入射された光波が受ける屈折率変動の影響は，

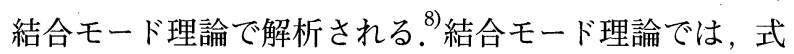
(1) と式 (2) を波動方程式に代入し, 高次微分と高次の回 折を無視することで，それぞれの電場振幅間の関係が， 結合モード方程式：

$$
\left\{\begin{array}{l}
\frac{d A(z ; \lambda)}{d z}=-i \delta A(z ; \lambda)-i \kappa B(z ; \lambda) \\
\frac{d B(z ; \lambda)}{d z}=i \delta B(z ; \lambda)+i \kappa A(z ; \lambda)
\end{array}\right.
$$

で与えられる。ここで, $A(z ; \lambda), B(z ; \lambda)$ は波長 $\lambda$ の前進 波, 後退波の電場振幅を表している，また，ここでは簡 単のために, ファイバー中の伝ぱの途中で発生する損失 は無視している. 式 (5)中の $\delta$ は自己結合定数で，ブラ ッグ波長からのズレ量による位相の変移を表し,

$$
\delta \equiv \frac{2 \pi \bar{n}}{\lambda}-\frac{\pi}{\lambda_{B}}
$$

と与えられる. $\delta$ は前進波から前進波, 後退波から後退 波間のエネルギー移動を表す定数である。火は相互結合 定数を表し，

$$
\kappa=\frac{\pi \Delta n}{\lambda_{B}}
$$

と表される。 $\kappa$ は前進波, 後退波間のエネルギー移動に 関する定数である. 屈折率変化の振幅 $\Delta n$ に比例して大 きくなる.ここで, FBG 内の任意の位置 $z$ での局所的な 反射係数を，

$$
\rho=(z ; \lambda)=\frac{B(z ; \lambda)}{A(z ; \lambda)}
$$

で定義し, 式 (5)より $d \rho / d z$ を求めると, 微分方程式,

$$
\frac{d \rho(z ; \lambda)}{d z}=2 i \delta \rho(z ; \lambda)-\kappa \rho^{2}(z ; \lambda)+\kappa
$$

が得られる.この微分方程式は, FBGの一方の端では, 後退波は存在しないこと $(\rho(L ; \lambda)=0)$ を境界条件として 解かれ, FBGの他方の端 $z=0$ での反射係数 $r(\lambda)=$ $\rho(0 ; \lambda)$ を得る.ここまでの説明では， $\kappa, \delta$ は空間的に一 様として説明してきたが, 一般的には空間的な分布を示 す.そこで, 式 (9)はコンピュータを使用した数值的解 法で解かれることが一般的である.

\section{3 ファイバーブラッググレーティングの形成と評価}

著者らが行っている FBGの書込みについての原理光 学系を図 2 に示す. 書込み光源として波長 $248 \mathrm{~nm}$ の $\mathrm{KrF}$ エキシマレーザーを用いた。 使用したエキシマレーザー

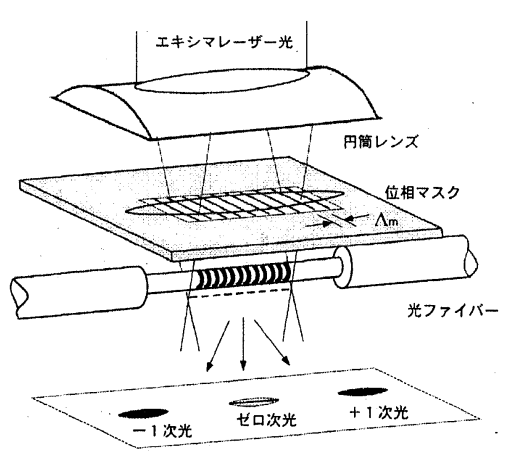

困 2 原理光学系

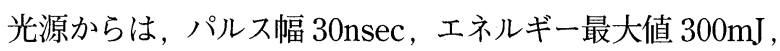
繰返し周波数最大 $20 \mathrm{~Hz}$ のパルスレーザー光が出力され る.パルスエネルギーと繰り返し周波数は光ファイバー への FBG 書込み条件により調整して使用した。 エキシ マレーザー光パルスは, 空間的なエネルギー密度を高く するために円筒レンズを用いて集光させた. 円筒レンズ は, 収差の影響を最小限に押さえるため曲面から光が入 射する様に使用する. 円筒レンズ集光面近くには，FBG を書込む光ファイバーを配置する. 光ファイバーは，フ アイバー表面を覆っている樹脂の部分を剥がし，クラッ ド層をむき出しにして配置する. FBG を書込む光ファイ バーは，水素ローディングと呼ばれる前処理を行い，工 キシマレーザー光に対する感度を向上させた後, FBGを 形成する.

光ファイバーと円筒レンズの間には, 位相マスクと呼 ばれる回折格子を配置する，位相マスクでの回折原理を 図 3 に示す。位相マスクには，一方の面に波形構造の回 折格子が刻まれている。この波形構造で，エキシマレー ザー光は回折され，0次の回折光（透過光）と \pm 1 次の回 折光そして高次の回折光を発生する.

位相マスクで回折された 1 次の回折光は，位相マス ク下方に干渉縞を発生させる. 位相マスクの波形構造の ピッチを $\Lambda_{m}$ とすると, 発生する干渉縞の間隔 $\Lambda$ は $\Lambda_{m}$ となる.この \pm 1 次の回折光により発生する間隔 $\Lambda$ の干 $/ 2$ 渉縞が FBG 書込みに使用される．縞間隔 $\Lambda$ の干渉縞 が光ファイバーに照射されると, 明るい縞の部分の屈折 率は高くなり, 暗い部分の屈折率は変化しないので, 縞 間隔 $\Lambda$ で屈折率の変動構造が発生することになる。この 縞間隔 $\Lambda$ の屈折率変化は, FBG 構造そのものでる。実 際の書込みの際に異なった格子間隔の FBG 構造を形成 するためには，形成したい格子間隔に対応した位相マス クが必要である。

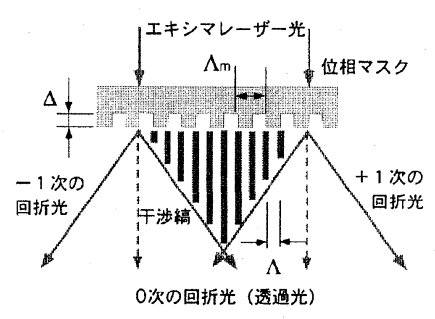

図 3 位相マスクによる回折 
位相マスクは，溶融石英ガラス板で作られて打り，紫 外領域光の吸収は無視できる程小さい。0次の回折光強 度は，FBG の書込みに使用する干渉縞のコントラストを 低下させるため，通常の位相マスクでは波形構造の凹凸 の深さ $\Delta$ を制御することで， 0 次の回折光（透過光）強 度が最小になり， \pm 1 次の回折光強度が最大になるように 設計されている。使用した位相マスクの 0 次の回折光強 度は入射光強度の約 $3 \%$ である. これに対して \pm 1 次の回 折光強度は約 35\% で, 残りの $27 \%$ の入射光は高次の回折 光となっている. \pm 1 次を含む高次の回折効率に波長依存 性はない. しかし， 0 次の回折光（透過光）の回折効率 は波形構造の凹凸深さと入射レーザー光波長の関係で決 定されるため，位相マスクは設計された波長でのみで使 用できる. ${ }^{10)}$

FBG の書込み時には, 図 4 に示す実時間観測システム により FBG 構造形成の時系列過程を実時間で観測しな がら書込みを行った. FBG 書込み用ファイバーは, 水素 ローディングの後, 実時間観測システム中に融着接続し てから書込みが行われる。このシステムでは, 広帯域光 源として ASE (Amplified Spontaneous Emission) 光源を 使用した. 光源からの光波は, 光アイソレータ, $3 \mathrm{~dB}$ カ プラーを介して，書込み用ファイバーに導かれ，その後 光スペクトルアナライザTに入力される．このスペクト ルアナライザでは，FBG の透過特性が観測される．3dB カプラーの一方の出力は光スペクトルアナライザ Rに接 続される。.これは，FBGの書込により発生する反射光の スペクトル観測に使用する。

光スペクトルアナライザ Tで観測された透過スペクト 儿例を図 5 (a)に示す。図 5 (a)には FBG 書込み前・後の 透過スペクトルも示している.

FBG を書込む前に観測されたスペクトルは光源の発光 スペクトルである. 広帯域光源からの出力光は約- $30 \mathrm{dBm}$ 程度で波長が長くなるに従って, 少しだけ弱くなる一様 なスペクトル分布を示す：書込み前のこの一様スペクト ルが参照スペクトルである.FBGの書込みを行った後で は, ブラッグ波長 $\lambda_{B}=1573 \mathrm{~nm}$ 近辺の光波スペクトルが 遮断され，透過しなくなっている.

光スペクトルアナライザ $\mathrm{R}$ で観測された反射スペクト 儿例を図 5 (b)に示す. FBG 書込み前には, 反射光は存 在しないので, 図 5 (b) 中, $-70 \mathrm{dBm}$ 程度のほぼ平らなス ペクトルの分布がまず観測される。一旦 FBG が書込ま れると, 透過スペクトルの変化と対応して, 波長 1573 $\mathrm{nm}$ 近辺に反射信号が発生する. 反射スペクトルの最大 値は，透過スペクトルの場合に定義した参照スペクトル となる. 図 5 (b)の場合, 波長 $1573 \mathrm{~nm}$ 付近のスペクトル

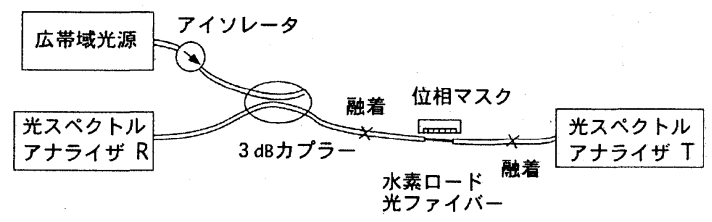

図 4 実時間観測システム
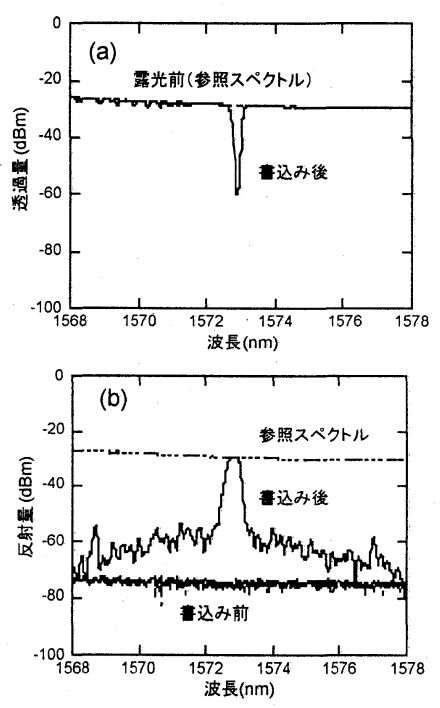

図 5 観測されたスペクトル，(a) FBG 書込み前後の 透過スペクトル，(b) FBG 書込み前後の反射スぺ クトル

が参照スペクトルと一致する. 反射スペクトルの測定結 果では, ブラッグ波長以外の波長域でもスペクトル強度 が増加する。これは FBG 構造形成のために発生した散 乱により発生する雑音である. 光通信用光学部品として FBG を利用する場合，この雑音成分は可能な限り除去す る必要がある.

通常の実時間観測の場合，参照スペクトルをあらかじ め測定しておき，参照スペクトルを基準にした変化量の みを観測する。透過・反射スペクトルの参照スペクトル との偏差を図 6 に示す.

この図の場合, ブラッグ波長において透過阻止量-30dB 反射量 $100 \%$ が観測されている．透過阻止量や反射量を 制御する場合，書込みを行いながらその光学特性を観測 することで，エキシマレーザーの照射時間を調整し， FBG の特性制御を行った。

エキシマレーザー光の照射時間の経過に従った透過ス ペクトル形状の変化についての観測結果を図 7 に示す. 露光時間が経過すると透過阻止量が増大する。同時に, 阻止中心波長が長波長側にシフトする。透過阻止量の増 加は, 露光により屈折率変動振幅 $\Delta n$ が増加するためで ある.また，阻止中心波長の長波長側へのシフトは，露 光に従って屈折率の変動構造が形成され結果的に平均屈 折率が増加するために，式 (4)のブラッグ波長が大きく

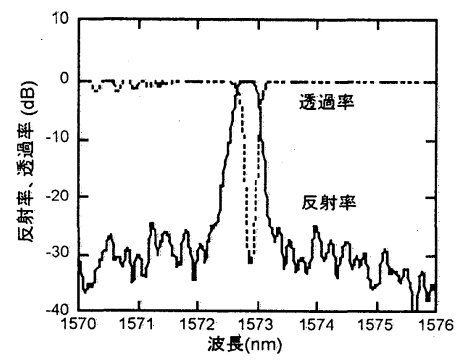

図 6 反射透過スペクトル 


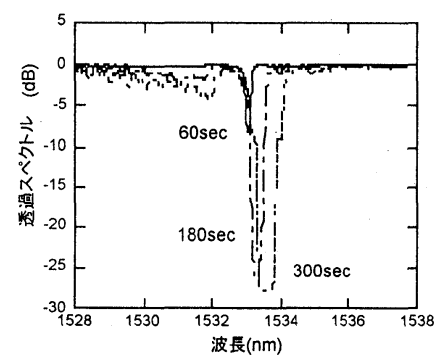

龱 7 透過スペクトルの時系列変化

\section{なるからである.}

露光時間と最大透過阻止量打よび中心波長の関係を 図 8 に示す。この図には, 中心波長だけでなく, 透過ス ペクトルが，-3dB を示す波長も示した。最大透過阻止 量は露光時間の経過に従って小さくなり, 露光時間 $200 \mathrm{sec}$ でほぼ飽和量に達している。阻止中心波長は露光 時間の増加とともに長波長側に変化している. 短波長側 の-3dB を示す波長は露光時間によりあまり変化せず長波 長側がより長波長側にシフトする特徴が顕著に表れてい る. 長波長側の-3dB を示す波長は, 中心波長のシフトに 対応して長波長側にシフトしている.

FBGの書き込みに際して, 光ファイバーを位相マスク の下部に確実に固定するために, 光ファイバーに張力を 与えた状態で FBGの書込みを行った. 光ファイバーに 張力を与えた機構を図 9 に示す.

光ファイバーの書込み部分の両端をそれぞれステージ 上に固定した，ステージの一方は固定ステージで，他方 は移動ステージになっており，移動ステージは一定の重 りで引っ張られている構造とした。この構造によりファ イバーに与える張力は, 移動ステージに与える重りを変 化させることにより正確に制御できる。

書き込み時に与えた張力の值に対する書き込まれた

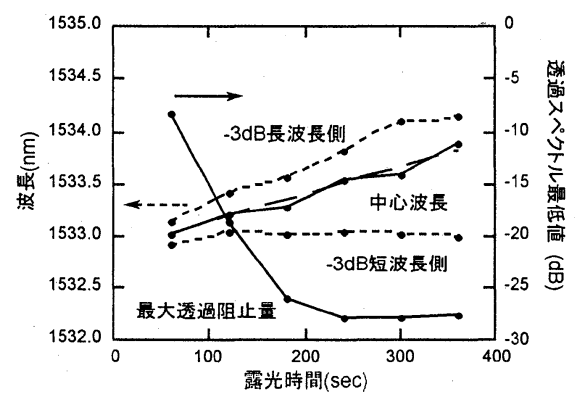

図 8 FBG 特性のの露光時間依存性

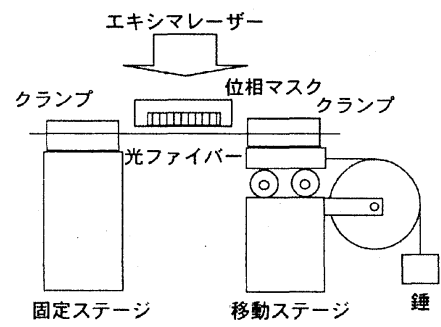

図 9 光ファイバーへの張力印加機構
FBG の特性を図 10 に示す．図では，張力を与えた状態 で，書込み終了時の最大透過阻止波長と，張力を除いた 状態での最大透過阻止波長を示している。また，得られ た最大透過阻止量も示す. 張力の有無で透過阻止波長が 変化する。これはブラッグ波長の張力依存性で，ひずみ 計測センサーとして応用されている. ${ }^{11)}$

書込み時に与えた張力に従って書込み時に観測される 透過阻止中心波長が線形に変化し, 張力を除いたあとで も線形に変化する。結果的に書込み時張力によって張力 解放状態での中心波長（ブラッグ波長）が線形に変化し， 単位重さあたりの中心波長（ブラッグ波長）の変化比は 約 $16 \mathrm{pm} / \mathrm{g}$ である。これは書込み時に与えた張力による 残留応力のためと考学られる. また，光ファイバー自身 が, 張力の有無により伸縮し, 実質的な格子間隔が変化 していると考えられる，この性質は，書込み時張力の制 御で, 異なるブラッグ波長の FBG 構造を形成できるこ とを示している. 0 から $250 \mathrm{~g}$ の間の鍾で張力を調整する ことで約 $4 \mathrm{~nm}$ の範囲で FBG の示すブラッグ波長を変化 させることが可能である. ${ }^{12}$

最大透過阻止量も書き込み時張力に依存して变化す る. 鍾の重さが $200 \mathrm{~g}$ 以下の時は同程度の阻止量を示す が，張力が大きい場合に阻止量が小さくなる傾向がある. これは張力が大きいため, 光ファイバーの固定部分が滑 ったり，レーザー光の照射によって光ファイバーが伸縮 するためと考えている。しかし，適当な張力を与えない で書込みを行うと, レーザー照射中のファイバー固定が 不安定で十分な書込及を行えない。適度な張力を与えた 状態で書込みを行うのが効果的である.

FBG を書き込む光ファイバーの光感度や屈折率変化量 を増大させるために, 水素ローディングと呼ばれる前処 理を行う．水素ローディング条件と形成された FBG 特 性の関係について考察した。光ファイバーは, 通信用フ アイバーとして一般的な SMF28（コーニング社製）と， 低カットオフ波長ファイバーとして良く使われる CS980 （コーニング社製）を使用した。水素ローディングは，室 温で気圧 $10 \mathrm{MPa}$ の水素雾囲気中に光ファイバーを封入 することで実行した，水素雲囲気中での封入日数と形成 した FBG の光学特性の関係を図 11 に示す.

困では，SMF28，CS980について書込んだ FBGの透 過阻止中心波長と透過阻止最大值を, 水素ローディング 日数について測定した結果である. 水素ローディング日

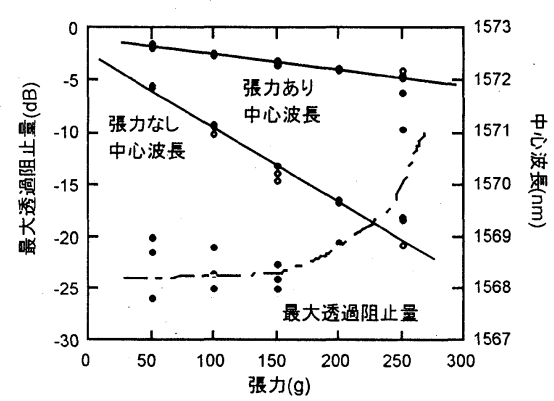

図 $10 \mathrm{FBG}$ 書込み時の張力に対する FBG の特性変化 


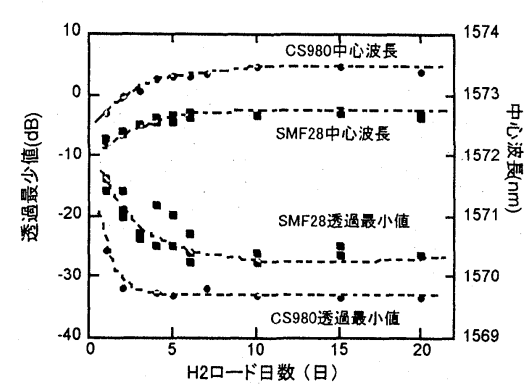

図 11 FBG の光学特性と水素ローディング日数

数が増加するに従って, 最大透過阻止量は増加する，両 ファイバーともに水素ロード日数 10 日を過ぎるとほぼ安 定した最大透過阻止量を示す。透過阻止中心波長は, 水 素ロード日数の増加に従って長波長側にシフトする。 こ ちらも 10 日を過ぎるとほぼ一定になっている. 水素ロー ディング日数の増加は, 光ファイバー中に拡散される水 素分子量を増加させる。観測結果から，今回行った実験 条件下では, 約 10 日間で, 水素分子の光ファイバー内 での拡散が，飽和状態となると考えられる，水素ローデ イングによってエキシマレーザー光に対する光感度は向 上し, 屈折率の変化量 $\Delta n$ も大きくなり, 最大透過阻止 量が大きくなっている．また， $\Delta n$ が水素ローディングに より大きくなるので, 結果的に屈折率平均値も大きくな り，ブラッグ波長も長波長側にシフトする。CS980は， SMF28 に比べてカットオフ波長が短い。これはコアを形 成する石英の $\mathrm{Ge}$ 添加量が多いためである。このため, SMF28 に比べて CS980 は大きい屈折率変化と大きい平 均屈折率を示す。

\section{4 多段型 FBG 光学フィルターデバイスの製作}

FBG はそのブラッグ波長相当の光波のみを反射する選 択的デバイスである，そこで，異なったブラッグ波長を もつ FBG を直列に多段型に配置することで，それぞれ の反射・透過特性の線形結合の反射・透過スペクトル特 性を得ることが可能である。図 12 に多段型 FBG の構成 原理を示す。一本の光ファイバーに屈折率格子の格子間 隔で決定するブラッグ波長が異なる FBG を直列に多段 型で構成すると，個々の FBGではそれぞれのブラッグ波 長に相当する光波をフィルタリングする。したがって全 体的には多波分の光波のフィルタリングを行うフィルタ 一として使用できる。

格子間隔の異なる位相マスクを使用して，一本の光フ アイバーの異なった部分部分に異なる FBG を形成する

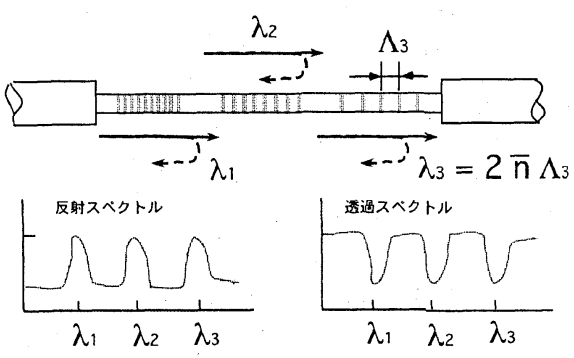

図 12 多段型 FBG フィルターの構成原理
ことで多段型 FBG を構成した８枚の位相マスクを用い て作成した 8 波対応の多段型 FBG の反射・透過スペク トルを図 13 (a)(b)に示す.この多段型 FBG は水素口ー ディングを行った SMF28光ファイバーを用いて構成し た。孚れぞれの FBGのブラッグ波長は，1530.03， 1534.676 , 1539.352, 1544.024, 1548.656, 1553.476, 1558.282，1563.068nm となった。これらの波長は，ITUT（国際電気通信連合）の SG15 G692 で標準化された 光通信で使用される光波長である.

反射スペクトルの各チャンネルの相似性も良好で，そ れでれの反射率も $0 \mathrm{~dB}$ と均一に作成できた。 反射スペク トルが示すノイズレベルは-25dB で, 光通信用光学部品 としてはさらなる改善が必要である。また，透過スぺク トルでは各チャンネル間で, 最大透過阻止量にばらつき が生じ，0dB 近辺にノイズも観測されている。

図 14 に特性を示した多段型フィルターは光通信用部 品評価用光源のフィルターに使用されている。反射型フ イルターとして使用されているため透過スペクトルのば らつきは問題とならなかった。 また，反射スぺクトルの ノイズレベルは，多段型フィルターを2段にして使用す ることで，-50dB まで改善して使用出来た.

多数枚の位相マスクを用いて多段型 FBG を形成する 方法の他に，図10で示したブラッグ波長の書込み時張 力依存性を利用することで，一枚の位相マスクのみで多 段型 FBG が構成できる.
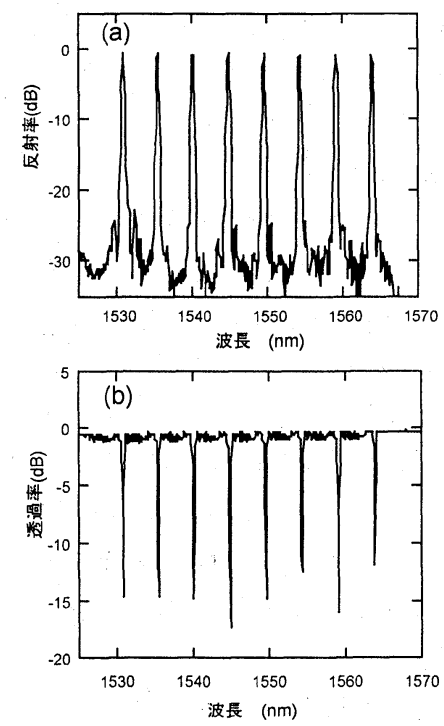

図 $138 \mathrm{ch}$ 対応多段型 FBG フィルターの特性

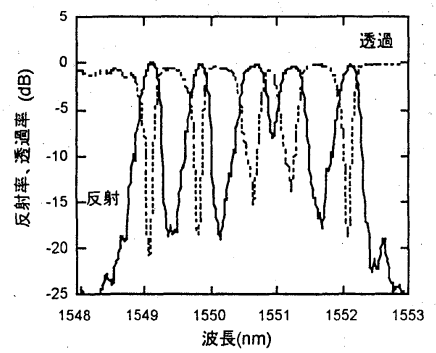

図 14 多段型フィルターの特性スペクトル 
図 10 より，16pm/g の割合で書込み時張力によりブラ ッグ波長が変化することが明かとなった，そこで，格子 間隔 $1073.1 \mathrm{~nm}$ の位相マスクを用いて実際に水素ローデ イングした SMF28光ファイバーに FBG 構造を形成した。 製作した多段型デバイスが示した透過・反射スペクトル を図 14 に示す。製作はまず，書込み時張力 $250 \mathrm{~g}$ を与え FBG を形成した。結果的に形成された FBG のブラッグ 波長は, 張力解放時で $1549.2 \mathrm{~nm}$ であった。 つぎに書込 み時張力を $200 \mathrm{~g}$ と設定して, 同じ光ファイバーの別の 部分に FBG を形成した.ブラッグ波長は，1549.8nmで あった。書込み時張力を $150 \mathrm{~g}, 100 \mathrm{~g}, 50 \mathrm{~g}$ と変化させ て，それぞれ書达及場所を変えて FBG 形成した。元 れぞれのブラッグ波長は，1550.7nm，1551.2nm， $1552.2 \mathrm{~nm}$ であった。 それでれの FBG の長さは $15 \mathrm{~mm}$ で， 間隔は $5 \mathrm{~mm}$ とした． 5 つの FBG からなる多段型フィル ターの全長は $100 \mathrm{~mm}$ ほどであった。

図では，それぞれの書込及時張力に対応する反射・透 過ピークが観測できる. 5 波対応の光フィルターとして 利用できる。しかし，書込み時張力制御で得られるブラ ッグ波長の変化幅は高々 $4 \mathrm{~nm}$ である. 現状の光通信技 術で要求されるチャンネル幅は約 $4 \mathrm{~nm}$ であり, 張力制御 の方式では対応できない.しかし，今後ますます光波長 の多重化が進むのは確実であり, 次世代の高密度多重光 通信技術に対応できる技術と考えている。

\section{5 ファイバーブラッググレーティング形成技術}

\section{に関する研究動向}

光ファイバー内での屈折率格子の形成は 1978 年に発 見された. ${ }^{13)}$ 当時は, 光ファイバーに入射した光と, ファ イバー端面での反射光との干渉で発生した干渉しまを介 して形成された屈折率格子であった。このため屈折率格 子で反射される光波長の制御も困難であった。 先の後, 紫 外線レーザーを用い，本報で紹介した位相マスクを用い る方法 ${ }^{14)}$ や，二光束干渉により発生する干渉しまを光つ アイバー側面から照射する方法等 ${ }^{15)}$ が紹介され，FBGの 製造研究は広く行われるようになり，現在に至っている.

最近では, 微細加工技術の進展に伴い光ファイバー内 で形成する屈折率変化構造の分布形状の制御が可能にな り, FBG の示すフィルター特性の応答スペクトル分布を 指定し，そのスペクトル形状を出力できる FBG の屈折 率変化構造をコンピューターシミュレーションにより最 適化する探究研究が行われている. $\left.{ }^{16)}, 17\right)$

近年行われている屈折率変化構造 $n(z)$ を図 $15(\mathrm{a}) \sim(\mathrm{d})$ に示す. 図 1 で示した FBG の原理同様, FBG で反射さ れる光波の中心波長（ブラッグ波長）はそれぞれの屈折 率変化構造を形成する基本周期 $\Lambda$ で決定される. しかし， 基本周期 $\Lambda$ の振動構造で形成される屈折率変化構造の包 絡線により, FBG フィルターの応答スペクトル形状が変 化する。

図 15 (a)はアポダイゼーション格子である. ${ }^{18)}$, 19) 図 1 の矩形の包絡をもつ FBG よりもサイドローブやノイズ強 度を低減できる. FBGの発見以来，反射スペクトルの整 形手法として，その製作技術は検討されている. 図

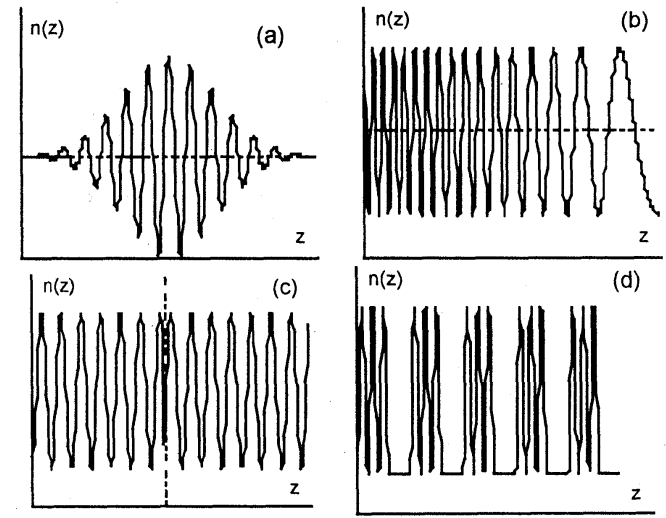

図 15 近年研究されている屈折率変化構造 $n(z)$, (a) アポダイゼーション格子, (b) チャープ格子, (c) 位相ずれ格子, (d) サンプルド格子

15 (b)はチャープ格子である．基本振動周期が，軸に沿 って変化しているため, ブラッグ波長に幅が発生し広い 波長範囲の光波に応答する FBG となる。 ${ }^{20}$ 近年, 超短パ ルス光の利用が注目され，チャープ FBG はパルス光の 分散制御 ${ }^{21)}$ への利用の可能性から注目されている。これ は，異なった波長成分が，空間的に異なった部分で反射 されるため, 反射される場所によって時間遅れを発生で きることを利用したものである. 図 15 (c) は位相ずれ格 子である. ${ }^{22)} \mathrm{FBG}$ を連続的に形成する際に基本振動の位 相を制御することで，その反射スペクトルの形状が制御 できる、図15(d)はサンプルド格子である。近年スーパ 一ストラクチャーとも呼ばれている. ${ }^{23}$ 通常の FBG を図 15 (d)に示すように特定周期で連続的に形成して, 特有 のスペクトル形状を実現する。個々の FBG の反射スペ クトルに，周期的に配置された構造の影響が重畳される と理解できる。 サンプルド格子を形成する基本格子にチ ヤープ格子を用いることで，スペクトル形状を変化させ たり ${ }^{24)}$ 基本格子間の屈折率を制御してスペクトル形状を 整えるなど設計上の自由度の多さから，今後有望である。

著者らは, 図 15 (b)に示す, チャープ格子を実際に作 成し，先の透過・反射スペクトルを測定した。作成した チャープ FBG の示す反射・透過スペクトルを図 16 に示 す. 図16では, チャープ格子の一部を形成せず，狭帯 域透過型フィルター（バンドパスフィルター）を形成し た例を示している. ${ }^{20)}$

チャープ格子は, チャープ付位相マスクを用いて形成

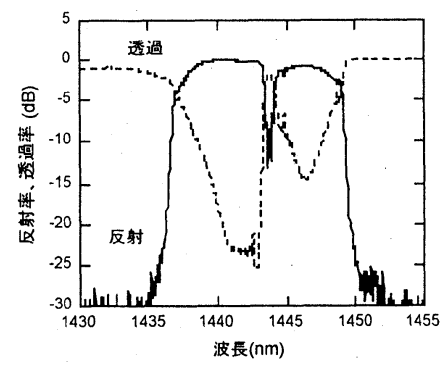

図 16 狭帯域透過型フィルターの特性スペクトル 
した，チャープ付位相マスクは，位相マスクの波型の凹 凸周期が一様ではなく，一方の端のピッチが狭く他方の 端のピッチが広くなっており，ピッチの変化量は一定割 合で変化する様に設計された位相マスクである，本実験 で使用した位相マスクは全長 $40 \mathrm{~mm}$ である。ピッチの変 化の割合は, $2 \mathrm{~nm} / \mathrm{cm}$ で, 位相マスク全体で, ブラック 波長が $8 \mathrm{~nm}$ 変化する FBG が作成できることになる．測 定結果から，ほぼ同等のスペクトル分布が得られている。

$$
6 \text { ま と め }
$$

光ファイバー中に屈折率分布構造を形成するだけで高 性能なブィターデバイスとなる FBG は今後ますます必 要とされるであろう。また，光ファイバー中に形成する 屈折率分布のより正確な制御技術が確立すれば，光ファ イバーデバイスの性能向上も期待できる.

本研究は, 新エネルギー・産業技術総合開発機構 (NEDO) の地域新生コンソーシアム研究事業として実施 された「光通信波長多重ファイバー型デバイスの開発」 プロジェクト（研究代表者：江島正毅）で得られた結果 をまとめたものである，御協力いただいた，関係者各位 に感謝する。

\section{参 考 文 献}

1) K. O. Hill and G. Meltz, J. Lightwave Technol., 15, 1263 (1997).

2) C. R. Giles, J. Lightwave Technol., 15, 1391 (1997).

3) A. D. Kersey, M. A. Davis, H. J. Patrick, M. LeBlanc, K. P. Koo, C. G. Askins, M. A. Putnam and E. J. Friebele, J. Lightwave Technol., 15, 1442 (1997).

4) D. P. Hand and P. St. Russel, Opt. Lett., 15, 102 (1990).

5) T.-E. Tsai, G. M. Williams and E. J. Friebele, Opt. Lett., 22, 224 (1997).

6) T. Erdogan, J. Lightwave Technol., 15, 1277 (1997).

7 ) 小山次郎, 西原 浩, “光波電子工学” 4 章（1978） コ口 ナ社.

8) A. Yariv and P. Yeh, "Optical waves in crystal", Chap. 11,
(1984) Wiley, New York.

9) B. Zhang and K. Raghavachari, Appl. Phys. Lett., 66, 2656 (1995).

10) Z. Xiong, G. D. Peng, B. Wu and P. L. Chu, J. Lightwave Technol., 17, 2361 (1999).

11) A. D. Kersey, Opt. Fiber Technol., 2, 291 (1996).

12) K. Nakagawa, Y. Takemura, R. Kunimoto, Y. Mizutani, S. Kimura, Y. Fukuyama, Y. Suzaki and S. Ejima, Jap. J. Appl. Phys. Pt.2, 41, L599 (2002).

13) K. O. Hill, F. Fujii, D. C. Johnson and B. S. Kawasaki, Appl. Phys. Lett., 32, 647 (1978).

14) K. O. Hill, B. Malo, F. Bilodeau, D. C. Johnson and J. Albert, Appl. Phys. Lett., 62, 1035 (1993).

15) G. Meltz, W. W. Morey and W. H. Glenn, Opt. Lett., 14, 823 (1989).

16) G. Cormier, R. Boudreau and S. Theriaut, J. Opt. Soc. Am. B, 18, 1771 (2001).

17) R. Feced, M. N. Zervas and M. A. Muriel, IEEE J. Quntum Electro., 35, 1105 (1999).

18) C. Martinez, S. Magne and P. Ferdinand, Appl. Opt., 41, 1733 (2002)

19) S. J. Mihailov, F. Bilodeau, K. O. Hill, D. C. Johnson, J. Albert and A. S. Holmes, Appl. Opt., 39, 3670(2000).

20) K. Sugden, L. Zhang, J. A. R. Williams, R. W. Fallon, L. A. Everall, K. E. Chisholm and I. Bennion, J. Lightwave Technol., 15, 1424 (1997),

21) M. Sumetsky, B. J. Eggleton and C. Martijin de Sterke, Opt. Express, 10, 332 (2002).

22) L. Wei and J. W. Y. Lit, J. Lightwave Technol., 15, 1405 (1997).

23) C. Martijn de Sterke and N. G. R. Broderick, Opt. Lett., 20, 2039 (1995).

24) C.-H. Wang, L. R. Chen and P. W. E. Smith, Appl. Opt., 41, 1654 (2002) 